\title{
MEMOIR
}

\section{KENNETH ASCOUGH USHERWOOD}

Kenneth Ascough Usherwood was born on 19 August 1904. He was educated at the City of London School and St John's, Cambridge. He simultaneously trained to be an actuary, becoming a student of the Institute in 1920 and passing the early parts of the examinations before starting his university studies in 1922 . When he was 21 years old he completed the actuarial examinations in the year in which he graduated-a unique achievement at that, and probably any other, time.

Kenneth had a long family link with the Prudential--his father was a member of the staff for 40 years. Kenneth was connected with the Prudential Assurance Co. from the time he entered their employment in 1925 until 1982 except for a break during the war. His career was wide ranging. He was initially engaged on actuarial work, and in 1931 was transferred to South Africa to become actuary of the newly formed branch in that country. He became involved in managerial duties when he became manager for the Near East in 1934 shortly after the formation of the branch there, and in his work for the Prudential, apart from a short period after his return to London in 1937, remained so involved until his retirement as an executive at the end of 1967.

Kenneth's managerial talent was reflected in rapid promotion. He became a deputy general manager in 1947 at what was then the very young age of 43 . His interests then ranged widely. His concern with people led him to pay particular attention to achieving a close understanding between staff and management. His interest in mechanization and electronics was of great value in the mechanization of clerical procedures and the introduction of computers, and he regarded the removal of routine work through these developments as making a vital contribution to staff relations. The Prudential's new computer centre at Reading, opened in 1987 by Kenneth, was named the Usherwood Centre. Throughout the period 1947-67 Kenneth was a major influence in guiding the growth of the Company in the United Kingdom and overseas.

Kenneth's managerial career developed at a time when the industry was concerned to maintain its independence and he served as Chairman of the Industrial Life Offices Association in 1966-67.

He was a director of the Prudential 1968-79 becoming Chairman 1970 75 and was elected to the honorary position of President 1979-82.

The fact that Kenneth ceased to be engaged in purely actuarial work did not diminish his commitment to the Institute. I le was an examiner 1940-42 and 1945-48 and scrved on Council 194667 apart from the customary one-year breaks. He was Honorary Secretary 1949-50, Vice-President 1954-56 and President 1962-64. He played a leading part in the planning of, and was co-president of the International Congress of Actuaries in London and Edinburgh in 1964, in which year he was made a Commander of the Order of the British Empire. He was Corresponding Member of the Deutsche Gesellschaft für Vericherungsmathematik, reflecting his interest in the overseas actuarial field.

Kenneth also maintained his interest in mathematics as is reflected by his appointments as Director of Statistics, Ministry of Supply in wartime 1941-45, as a member of the Gaming Board 1968-72 and by his discussions in the office with Frank Redington on abstruse mathematical problems.

His interest in nature and conservation, stimulated by that of his wife Mary, led to his appointment as Treasurer of the Field Studies Council 1969-77.

Kenneth was a man of impressive intellect with interests so wide ranging that he could converse on almost any subject which might arise while sometimes failing to initiate a discussion on a subject because no-one in the company knew anything about it. He was a stimulating and interesting conversationalist with a light touch. He could make quick decisions not because he saw issues as black and white but hecause he quickly saw, and was sensitive to, all aspects of a problem. He was concerned with people. He brought the best out of a management team and was a successful leader of staff at all levels. 
Music, the theatre and the arts were particular interests. Sport was not his speciality and he claimed to know nothing about cricket.

Kenneth valued the contribution made to the profession by the actuarial dining clubs and regularly attended meetings of the Actuaries Club until the time of his death. He died suddenly on 5 December 1988, leaving Mary his widow, a son from his second marriage and a daughter from his first.

R. S. SKERMAN 